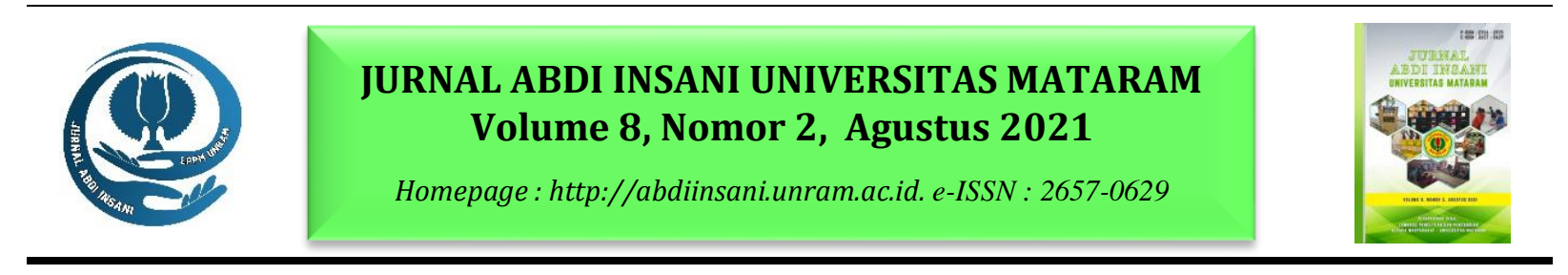

\title{
PEMANFAATAN MEDIA OPEN SOURCE SEBAGAI MEDIA PEMBELAJARAN ONLINE DI MASA PANDEMI COVID-19 SD NEGERI 1 TERONG TAWAH
}

\section{Utilization Of Open Source Media As Online Learning Media During The Covid-19 Pandemic Sd Negeri 1 Terong Tawah}

\section{Arik Aranta*, I Gede Pasek Suta Wijaya, Ario Yudo Husodo, Fitri Bimantoro, Gibran Satya Nugraha, Haidar Rahman}

Program Studi Teknik Informatika Universitas Mataram

Jl. Majapahit Nomor 62 Kota Mataram, Provinsi NTB

Alamat korespondensi: arikaranta@unram.ac.id

(Tanggal Submission: 1 Agustus 2021, Tanggal Accepted : 31 Agustus 2021)

\begin{abstract}
Kata Kunci : Abstrak :
Open source, E- SD Negeri 1 Terong Tawah merupakan sebuah Sekolah Dasar yang memiliki Learning, Guru, akreditasi A dan telah menerapkan kurikulum 2013 (K-13). Sekolah Dasar Sekolah Dasar, tersebut memiliki 10 Guru, 136 siswa laki-laki, 102 siswa perempuan, 6 ruang Covid-19 kelas, 1 perpustakaan dan masih belum memiliki akses internet. Seiring dengan penerapan belajar dari rumah pada masa Pandemi Covid-19, SDN 1 Terong Tawah belum menerapkan pembelajaran berbasis e-learning, pembelajaran berbasis e-learning memiliki berbagai macam bentuk, seperti dapat melalui media website. Para Guru SD Negeri 1 Terong Tawah dan Staff akademik belum terbiasa dalam pembelajaran secara daring. Kegiatan pengabdian kepada masyarakat ini bertujuan untuk mengajak para guru untuk dapat mengelola konten kreatif agar media pembelajaran berbasis online yang diterapkan dapat mudah dipahami dan menarik digunakan, dan tidak kalah penting aplikasi digunakan dimana harus dapat menjawab permasalahan, dimana setiap peserta didik yang tidak semua memiliki perangkat smartphone. Hasil pelatihan menunjukkan dari 12 peserta yang mengikuti pelatihan ini yang terdiri dari 3 poin penilaian, kurang bermanfaat, cukup bermanfaat dan sangat bermanfaat, seluruh peserta atau $100 \%$ menyatakan kegiatan ini sangat bermanfaat, serta keseluruhan saran dan masukan yang didapat dari Guru SD yang dilatih mengharapkan pelatihan serupa dilaksanakan kembali untuk meningkatkan pemahaman penggunaan media online.
\end{abstract}

Panduan sitasi / Citation guidance (APPA $7^{\text {th }}$ edition) :

Aranta, A., Wijaya, I. G. P. S., Husodo, A. Y., Bimantoro, F., Nugraha, G. S., \& Rahman. H. (2021). Pemanfaatan Media Open Source Sebagai Media Pembelajaran Online Di Masa Pandemi Covid-19 Sd Negeri 1 Terong Tawah. Abdi Insani, 8 (2), 249-258. http://doi.org/10.29303/abdiinsani.v8i2.417 


\section{PENDAHULUAN}

Teknologi informasi dan komunikasi yang berkembang semakin cepat memberikan dampak positif bagi kemajuan dunia pendidikan di Indonesia. Pendidikan di Indonesia telah mengalami inovasi dari tahun ke tahun dalam bentuk sarana prasarana yang digunakan untuk memperlancar jalannya kegiatan mengajar, maupun keseluruhan sistem pendidikan. Hal tersebut bertujuan agar pendidikan menjadi lebih efektif, efisien dan menarik bagi siswa maupun guru. terlebih saat ini dunia pendidikan merupakan salah satu sektor yang terdampak Covid-19 (Dwiyansaputra et al., 2021). SD Negeri 1 Terong tawah merupakan Sekolah Dasar yang memiliki akreditasi A yang terletak di Kecamatan Labuapi, Provinsi Nusa Tenggara Barat dan telah menerapkan kurikulum K-13, Sekolah Dasar tersebut menurut data yang tercatat pada data Kemendikbud memiliki 10 Guru, 136 siswa laki-laki, 102 siswa perempuan 6 ruang kelas 1 perpustakaan dan masih belum memiliki akses internet (Kemendikbud, 2021).

Seiring dengan penerapan belajar dari rumah pada masa Pandemi Covid-19, SDN 1 Terong Tawah belum menerapkan pembelajaran berbasis E-learning, dikarenakan keterbatasan sumberdaya. Pembelajaran berbasis E-learning memiliki berbagai macam bentuk, seperti dapat melalui media website yang didaftarkan oleh sekolah pada penyedia domain atau bekerjasama dengan mitra, atau aplikasi zoom yang saat ini marak digunakan Zaenuri \& Prastowo (2021), yang dalam hal ini memerlukan kebijakan khusus dalam proses implementasinya dikarenakan diperlukan biaya yang khusus dalam pengelolaan dan perawatannya. Selain zoom google google classroom juga merupana sebuah pilihan yang dapat digunakan untu mengelola konten pembelajaran daring namun dalam proses penerapannya memerlukan pelatihan khusus kepada guru dan siswa yang akan menggunakan (Switrayni et al., 2021). Penerapan E-learning akan lebih memungkinkan apabila user/pengguna aplikasi adalah siswa Sekolah Menengah Pertama, yang lebih terbiasa melakukan baca tulis, namun akan menimbulkan pertanyaan bagaimana mengimplementasikan media pembelajaran berbasis E-learning pada siswa Sekolah Dasar yang pada dasarnya siswa dengan berbagai latar belakang ekonomi wali/orangtua/peserta didik, serta kesiapan peserta didik dalam mengoperasikan perangkat elektronik, selain hal tersebut permasalahan lain seperti kemampuan penyediaan perangkat digital guna mendukung proses pembelajaran online yang memerlukan perangkat khusus, seperti smartphone laptop/komputer .

Dalam hal ini selain Wali murid diharuskan menukung dari segi materiil tak terlepas dari sisi Guru pengajar SD Negeri 1 Terong Tawah dan Staff akademik dalam hal ini diharapkan memiliki kemampuan untuk dapat mengelola konten kreatif agar media pembelajaran berbasis online yang diterapkan, tidak membosankan dan yang paling utama mudah untuk digunakan dimana harus dapat menjawab permasalahan setiap peserta didik yang dimana tidak semua siswa/siswi memiliki perangkat smartphone, yang umumnya dalam penerapan pembelajaran daring sering ditemui kendala seperti koneksi internet, media daring yang mengalami masalah eror, hingga munculnya rasa bosan dari peserta didik (Saputra, 2017) sehingga membuat siswa dan guru harus dapat beradaptasi terhadap penggunaan media online, yang dimana hal ini memberikan tantangan kepada siswa/peserta didik ataupun kepada guru/pendidik (Widodo, 2021). Melalui kegiatan pelatihan penggunaan E-learning yang bersifat open source diharapkan dapat menjadi solusi yang dapat menjawab pertanyaan yang dihadapi, dimana aplikasi yang dikembangkan merupakan media gratis handal, mudah dioperasikan, dan dapat dibuka pada berbagai perangkat yang terkoneksi internet seperti laptop/komputer/smartphone, dimana dalam hal ini apabila terdapat peserta didik yang tidak memiliki perangkat yang dibutuhkan, maka masih 
dimungkinkan untuk dapat menggunakan smartphone saudara atau orang terdekat dikarenakan sistem yang ditawarkan bersifat web-based sehingga tidak memerlukan proses instalasi.

\section{Tujuan}

Tujuan dari kegiatan pelatihan penggunaan e-learning sebagai pelatihan media pembelajaran berbasis pembelajaran daring (dalam jaringan) ini adalah sebuah pelatihan media pembelajaran yang diberikan kepada guru dan staf akademik SD Negeri 1 Terong Tawah, tentang tatacara penggunaan dan elearning open source yang disediakan oleh platform google, seperti google form, google spread sheet, youtube, yang dikolaborasikan Whatshapp dalam penyampaian proses pembelajaran.

\section{Manfaat}

Adapun manfaat dari kegiatan pelatihan penggunaan media e-learning sebagai media pembelajaran berbasis perangkat online internet adalah sebagai berikut:

1. Bagi siswa SD Negeri 1 Terong Tawah, dapat menggunakan e-learning sebagai media untuk melakukan proses pembelajaran secara daring, yang dapat diakses kapan saja dan melalui berbagai media seperti laptop,smartphone, komputer, tablet, yang dimana peserta didik tidak diwajibkan memiliki smartphone pribadi.

2. Bagi guru SD Negeri 1 Terong Tawah dapat meningkatkan kompetensi guru dan staff akademik dalam hal penggunaan teknologi dalam proses pengajaran sehingga dapat memudahkan para guru untuk memantau perkembangan belajar siswa, sehingga dapat secara cepat menentukan strategi materi ajar yang perlu diberikan ke siswa.

\section{METODE KEGIATAN}

Lokasi Pelatihan SD Negeri 1 Terong Tawah terletak di JI. Darul Hikmah No.11a, Terong Tawah, Kec. Labuapi, Kabupaten Lombok Barat, Nusa Tenggara Barat, Jarak tempuh yang dilalui apabila berangkat dari Universitas Mataram berkisar 14 Menit menggunakan kendaraan roda empat. Kegiatan pelatihan ini dilaksanakan secara bertahap yang diawali dengan survey lokasi, pengurusan izin kegiatan antar lembaga, penyusunan bahan atau materi pelatihan, penentuan jadwal terkait kesediaan waktu para guru, untuk dapat mengikuti pelatihan. Selanjutnya, secara teknis pelaksanaan kegiatan ini berupa pelatihan penggunaan E-learning sebagai media pengajaran berbasis media online.

Pemilihan SD Negeri 1 Terong Tawah sebagai lokasi pengabdian dikarenakan kurang efektifnya pelaksanaan pembelajaran di masa pandemi dikarenakan sekolah tidak memiliki fasilitas E-learning dan dimana terdapat masalah lain yakni peserta didik tidak semua memiliki laptop dan smartphone, sehingga solusi yang kami berikan adalah melakukan pelatihan bagaimana cara memanfaatkan E-learning berbasis open source yang sebagai media pembelajaran berbasis smartphone android/komputer tanpa installasi dan tidak berbayar sehingga memukinkan peserta didik yang memiliki kendala ekonomi dapat menggunakan perangkat sanak saudaranya untuk mengakses media pembelajaran berbasis online yang disediakan.

Adapun peralatan yang diperlukan dalam pengabdian dalam bentuk pelatihan ini berupa:

1 Perangkat komputer/Laptop/Smartphone;

2 Koneksi Internet

3 LCD Projector 
Materi Pelatihan

5 Ruang Kelas

6 LKS/Buku Ajar

7 Snack dan Konsumsi Kegiatan

Materi yang akan disampaikan pada saat pelatihan akan dibagi menjadi 2 (dua) sub pokok pembahasan, yaitu pertama pembahasan mengenai pentingnya penggunaan E-learning untuk meningkatkan efisiensi dan efektifitas pembelajaran, terutama untuk penggunaanya dalam proses pengambilan nilai latihan pembelajaran, pembahasan yang kedua meliputi tata cara management Elearning yang meliputi tata cara pembuatan file pembelajaran, pengelolaan google drive serta aktivitas E-learning, pemasangan peralatan video online, pembuatan account google, pengelolaan hasil penilaian lainnya yang dapat menunjang proses belajar mengajar. Beberapa metode pelatihan yang akan digunakan untuk melaksanakan kegiatan pembelajaran daring ini

Antara lain beberapa metode yang dimaksud adalah Metode ceramah, digunakan untuk memberikan penjelasan mengenai manfaat dan pentingnya penggunaan e-learning, untuk meningkatkan efisiensi dan efektivitas pembelajaran, serta memberikan motivasi kepada guru. berikutnya dilanjutkan dengan Metode tutorial digunakan agar peserta pelatihan dapat benar-benar memahami setiap langkah yang diberikan oleh tutor, dengan cara mengikuti setiap petunjuk. Pada metode Praktik ini peserta pelatihan mempraktikkan setiap langkah kerja sesuai dengan materi pelatihan yang diberikan dan sesuai dengan arahan dari tutor.

Metode tanya jawab dan diskusi, merupakan tahap akhir dimana Metode tanya jawab atau diskusi sangat penting bagi peserta pelatihan karena metode ini memberikan kesempatan pada peserta untuk menggali pengetahuan lebih jauh lagi mengenai E-learning dan juga pengalaman setelah praktik penggunaanya. Evaluasi kegiatan pelatihan penggunaan E-learning sebagai media latihan ujian berbasis perangkat terkoneksi internet dilaksanakan pada saat pelaksanaan kegiatan dengan melihat partisipasi peserta dalam mengikuti pelatihan, pemahaman materi, dan mempraktekkan proses penggunaan $\mathrm{E}$ learning, pengelolaan google drive, pemahaman pembuatan video online disamping itu, komunikasi lanjutan dapat dilakukan melalui Whatsapp untuk melakukan diskusi tentang kendala-kendala yang dihadapi selama percobaan penggunaan E-learning untuk pelaksanaan proses pembelajaran.

\section{HASIL DAN PEMBAHASAN}

Kegiatan Pengabdian dilaksanakan Pelatihan SD Negeri 1 Terong Tawah terletak di Jalan Darul Hikmah No.11a, Terong Tawah, Kec. Labuapi, Kabupaten Lombok Barat, Nusa Tenggara Barat, Kegiatan pelatihan ini dilaksanakan secara bertahap yang diawali dengan survey lokasi, pengurusan izin kegiatan antar lembaga, penyusunan bahan atau materi pelatihan, penentuan jadwal terkait kesediaan waktu para guru, untuk dapat mengikuti pelatihan. Selanjutnya, secara teknis pelaksanaan kegiatan ini berupa pelatihan penggunaan e-learning sebagai media pengajaran berbasis media online, yang dilaksanakan mulai pukul mulai pukul 09:00 WITA.

Kegiatan pengabdian ini diawali dengan penjelasan terkait peranan guru yang saat ini di diharuskan dapat mendorong peningkatan prestasi akademik murid, mengajar dengan kreatif, mengembangkan diri secara aktif, yang sejalan dengan program Guru Penggerak milik KEMDIKBUD, yang mana seorang guru penggeral diharapkan dapat mendorong tumbuh kembang murid secara holistik, menjadi mentor bagi guru lain untuk proses pembelajaran hingga seorang guru haruslah dapat menjadi 
teladan dan agen dari transformasi bagi ekosistem pendidikan. Dimana pada tahap ini guru diharapkan dapat beradaptasi dengan model pembelajaran yang mengalami perubahan, dimana media pembelajaran saat ini haruslah dapat beradaptasi dengan perkembangan teknologi informasi, yaang nantinya dapat memberikan kemudahn bagi guru hingga dapat mengembangkan media ajar interaktif. Pada tahapan berikutnya dilakukan proses memberikan pengarahan terkait pembuatan konten kreatif dalam proses pembelajaran menggunakan google form. masalah yang dihadapi dalam pemanfaatan media open source ini dalam proses pembelajaran, adalah pemberian pemahaman terkait kegunaan dan fitur-fitur yang tersedia pada software yang digunakan seperti google form, google drive, youtube, whatsapp, sehingga dapat memaksimalkan proses pembeljaran melalui media daring.

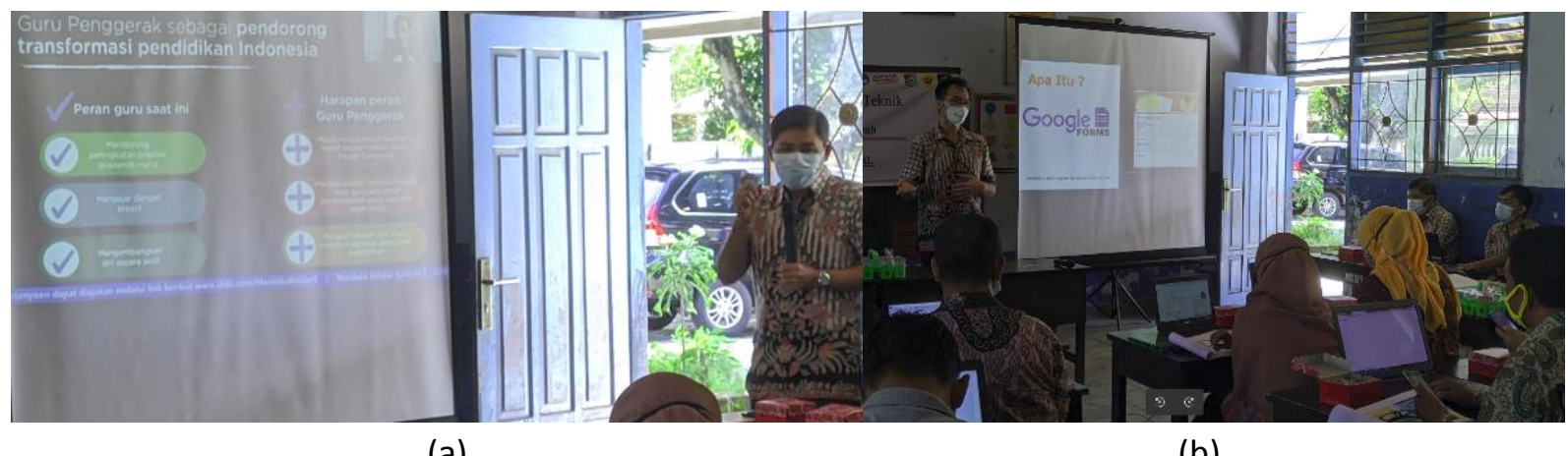

(a)

(b)

Gambar 1. (a)Penyampaian Materi Guru Penggerak, (b)Penyampaian Materi Media Open Source

Setelah memberikan motivasi kepada peserta pelatihan terkait pentingnya penggunaan media online dalam proses pembelajaran. Tahapan berikutnya adalah perancangan konten kreatif, menggunakan gabungan beberapa aplikasi seperti google form, google search dan youtube dan whatsApp digunakan dalam mendukung proses pembuatan materi pembelajaran yang awal mulanya berbentuk media cetak atau berasal dari buku cetak, berubah menjadi media E-learning dengan bentuk output seperti pada hasil tampilan berikut.

\section{SD N 1 Terong}

\section{Tawah}

Kelas VI Semester I

Mata pelajaran : Matematika (6a)

Tugas Mandiri :1

Halaman :23

arikaranta@unram.ac.id

(not shared) Switch accounts

(a)
4. Tuliskan nilai a, b, c, d. 25 points

*

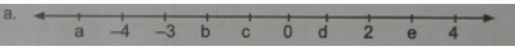

a. $a=-5, b=-2 c=-1 d=1 \quad e=3$

b. $a=-5, b=-2 \quad c=-1 d=1 e=3$

c. $a=-5, b=-2 c=-1 d=1 \quad e=3$

(b)

Gambar 2. (a) Model soal berbasis online dengan soal bergambar, (b) Model soal online dengan jawaban bergambar dan tampilan video Penjelasan 
Pada tahapan pembuatan konten kreatif para peserta guru diberikan pelatihan menata konten yang berasal dari buku cetak untuk selanjutnya menjadi konten dalam bentuk digital, seperti penginputan gambar, text dan video, pada media pembelajaran yang dikembangkan. Setelah dirasa demonstrasi tersampaikan dalam contoh proses pembuatan konten kreatif, kegiatan yang dilakukan setelah proses pemaparan bentuk konten kreatif adalah melakukan praktek dalam pembuatan kon kreatif menggunakan google form kepada guru yang hadir di lokasi.

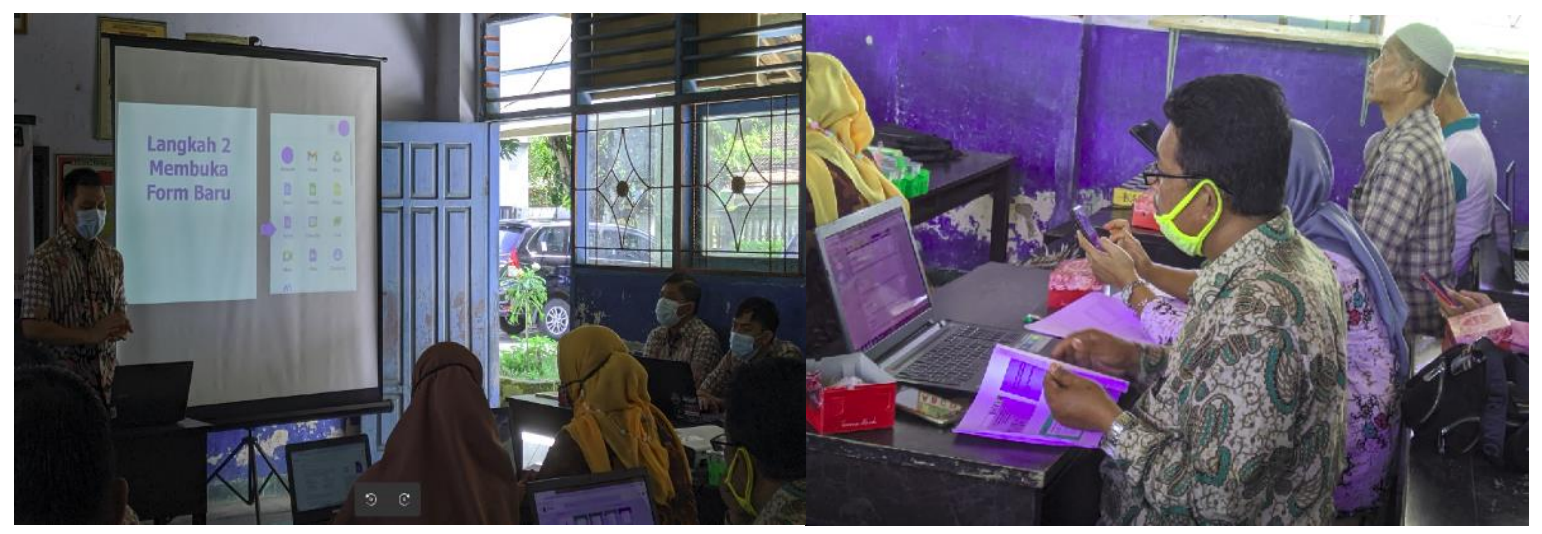

(a)

(b)

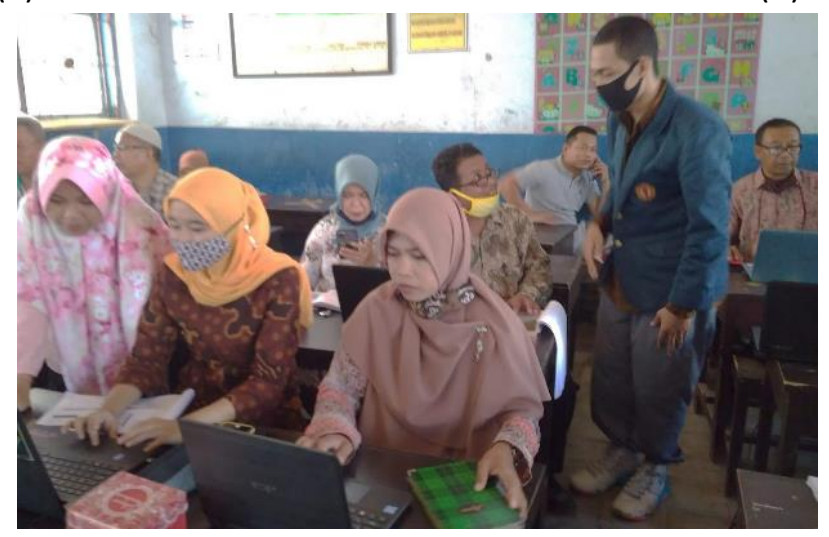

(c)

Gambar 3. (a) Pengarahan Penggunaan google form, (b)Peserta mencoba mengisi google form, (c) Mahasiswa mendampingi peserta dalam proses praktek

Pada gambar 3 (a), peserta diberikan pengarahan penggunaan google form, pengarahan proses mengisi konten dalam bentuk text, gambar, atau video, materi yang digunakan menggunakan materi buku Lembar kerja siswa (LKS), Matematika (6a). Kegiatan yang dilakukan oleh guru guru meliputi, menyalin/menulis soal pada halaman google form, mempelajari proses penginputan soal dalam bentuk gambar pada google form, mencoba melakukan penginputan video dalam google form, setelah peserta mencoba melakukan proses pengisian google form melalui komputer peserta diberikan pengarahan melalui tampilan smartphone, dengan harapan peserta dapat melakukan proses pengisian meliputi insert, update dan delete melalui perangkat smartphone.

Sebagaimana Gambar 4 (a), Pemateri memberikan pengarahan terkait proses pengisian google form melalui perangkat smartphone, setelah terselesaikan proses pengisian peserta melakukan serta 
mencoba membuka file google form yang telah dibuat melalui perangkat smartphone, dengan melakukan share link kepada rekan-rekannya dan mencoba menjawab mengisi google form yang telah dibuat oleh rekan-rekannya.

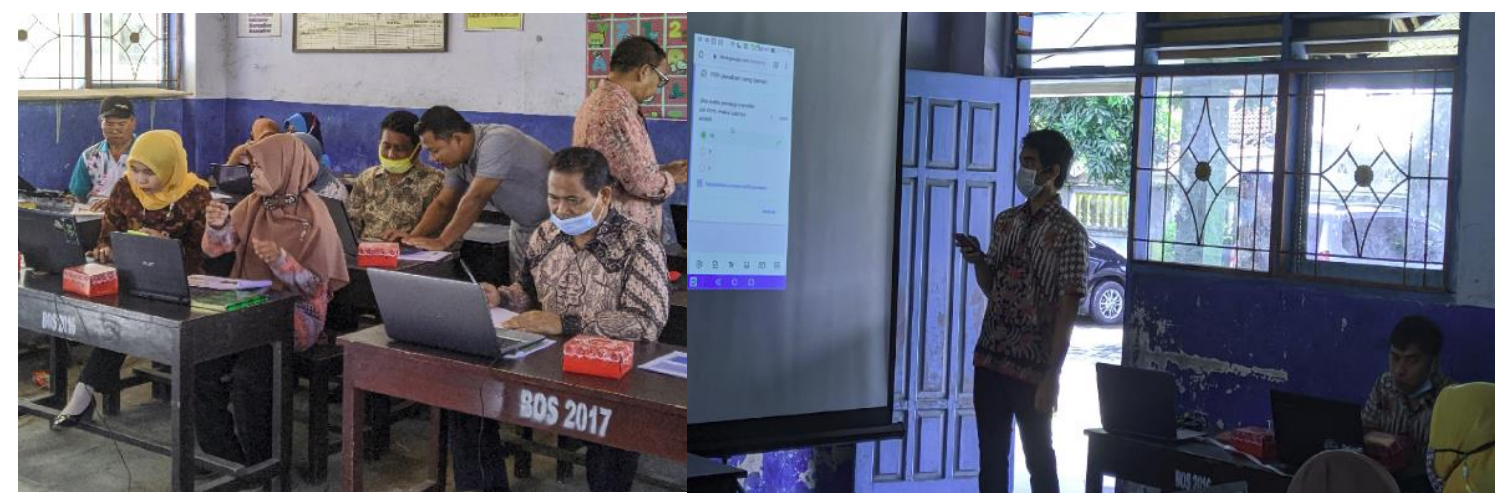

(a)

(b)

Gambar 4. (a) Peserta praktek proses pengisian google form (b) Pemberian arahan pengisian google form melalui perangkat smartphone

Setelah proses pengisian materi, acara dilanjutkan dengan sesi tanya jawab dan evaluasi kegiatan seperti disampaikan seperti pada Gambar 5 (a) dan (b), sebagai penutup kegiatan, beberapa pertanyaan yang diajukan oleh pihak sekolah adalah, diantaranya bagaimana prosedur agar kegiatan serupa dapat dilakukan kembali di SDN 1 Terong Tawah, dimana taggapan yang dapat diberikan adalah, kegiatan pengabidan ini merupakan program institusi tahunan sehingga diperlukan pembukaan program pengabdian sehingga dapat mendukung kegiatan serupa untuk diadakan, namun apabila pihak penyelenggara bersedia mengundang pemateri untuk mengisi kegiatan serupa maka Prodi Teknik Informatika akan mengusahakan utuk diadakan kembali. Setelah sesi tanya jawab usai peserta diminta mengisi link survey kegiatan untuk proses evaluasi hasil kegiatan dan sebagai data acuan pembuatan sertifikat kegiatan dan pembagian konsumsi.

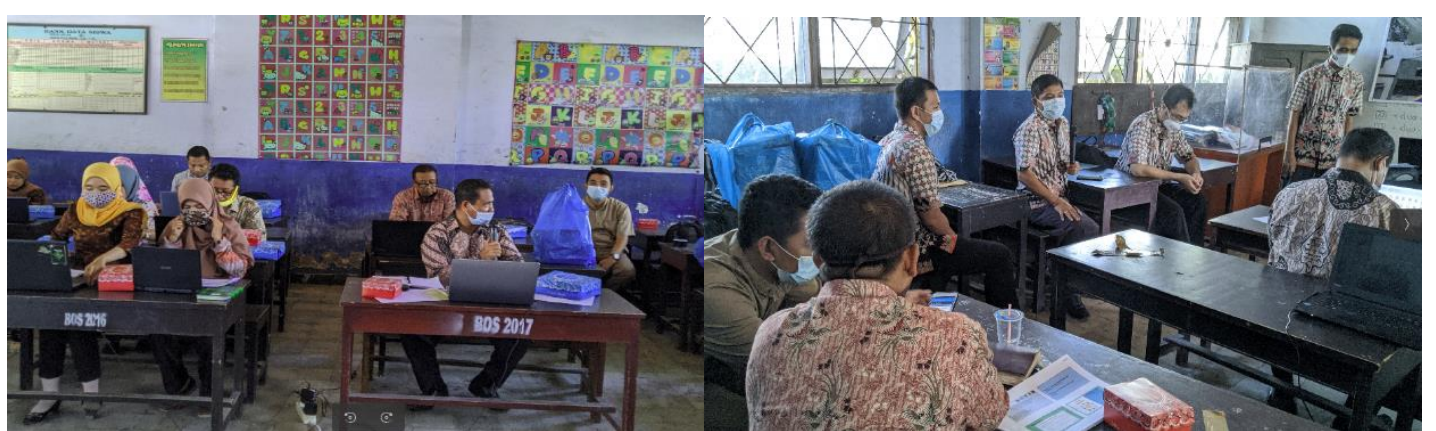

(a) (b)

Gambar 5 (a) Peserta kegiatan melakukan proses pengajuan pertanyaan (b) Pemateri memberikan tanggapan terkait pertanyaan yang diberikan

Setelah melakukan proses pelatihan, peserta diminta untuk mengisi form evaluasi, sehingga dapat disimpulkan tingkat kebermanfaatan dari pelatihan yang dilakukan sebagaimana hasil grafik pada 
gambar 6(a) dan (b), dimana pada grafik tersebut menunjukkan dari dua belas data yang diisikan oleh peserta, dua belas peserta menyatakan pelatihan yang dilakukan dirasa sangat bermanfaat, dan peserta bersedia mengikuti kegiatan serupa apabila dilaksanakan kembali.

Apakah menurut anda apakah pelatihan ini bermanfaat ?

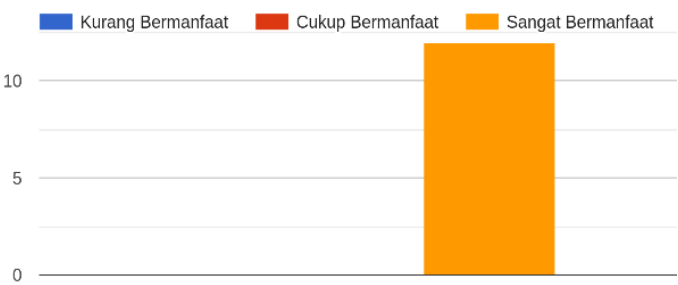

(a)
Apabila dilaksanakan kembali apakah anda tertarik untuk mengikuti? 12 responses

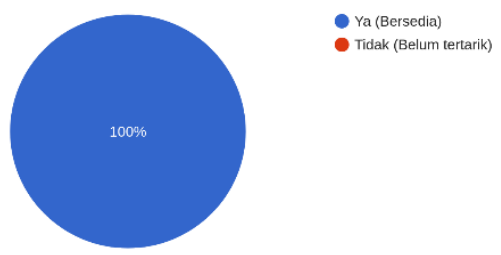

(b)

Gambar 7. (a) Hasil grafik pertanyaan kebermanfaatan kegiatan (b) Hasil grafik dengan pertanyaan keberminatan mengikuti kegiatan serupa

Berdasarkan hasil pengabdian yang dilakukan maka memiliki hasil seperti pada tampilan grafik pada Gambar 7, (a) dan (b) yang dimana dapat dinyatakan kegiatan yang dilakukan bermanfaat dan peserta bersedia apabila, diadakan kegiatan serupa pada Sekolah Dasar Negeri 1 Terong Tawah. Serta pada link survey yang dibagikan sembilan peserta mengisi kolom komentar dengan beberapa pernyataan sebagaimana Gambar 8.

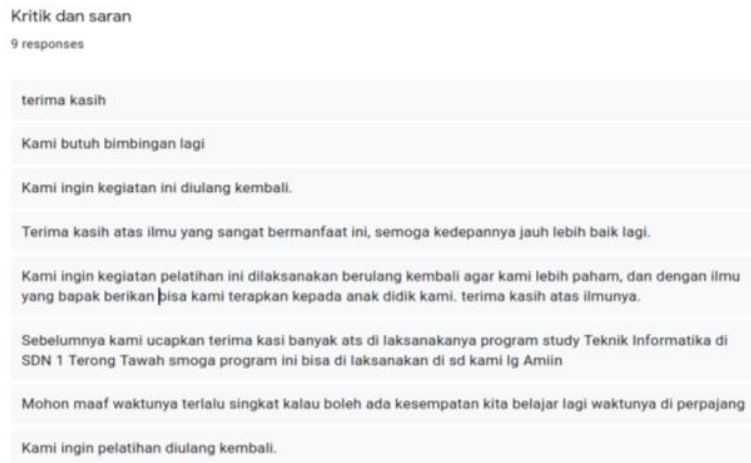

(a)

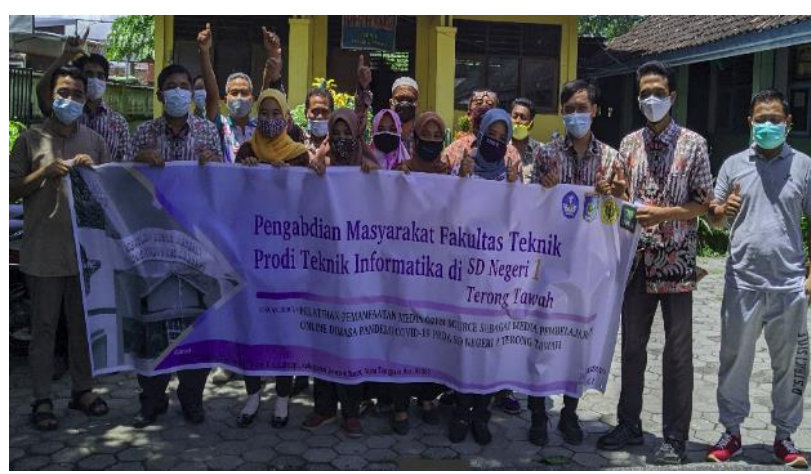

(b)

Gambar 8. (a)Kritik dan saran peserta kegiatan (b) Foto bersama selama kegiatan

Terdapat 9 review kegiatan yang didapatkan dari pelatihan yang telah dilakukan diantaranya, peserta berkeinginan apabila kegiatan serupa dilakukan kembali sehingga peserta dapat lebih memahami materi yang diberikan, dan beberapa harapan seperti diperlukannya bimbingan tambahan untuk mempelajari modul daring yang telah dibagikan, di Penghujung acara di tutup dengan sesi foto bersama dengan menerapkan protokol kesehatan. 


\section{KESIMPULAN DAN SARAN}

\section{Kesimpulan}

beberapa poin kesimpulan yang dapat diperoleh melalui kegiatan pengabdian kepada masyarakat ini adalah sebagaimana berikut :

1. Telah dilakukannya kegiatan Pengabdian Kepada Masyarakat (PKM) Guru dan Staff Akademik Sekolah Dasar Negeri 1 Terong Tawah, Labuapi Nusa Tenggara Barat .

2. Kegiatan PKM meliputi pelatihan penggunaan media open source dalam meningkatkan efektifitas penggunaan media daring di masa pandemi Covid- 19.

3. Dengan dilakukannya kegiatan ini membuat Guru SD Negeri 1 Terong Tawah yang mengikuti pelatihan, mengetahui proses pembuatan google form pembagian link dan pemantauan nilai hasil pengisian, untuk mendukung proses belajar mengajar di masa pandemi/ berbasis online.

Saran

Beberapa poin saran yang dapat diperoleh dari kegiatan Pengabdian Pada Masyarakat ini adalah sebagaimana berikut :

1. Diperlukannya program pengabdian masyarakat pada SD Negeri 1 Terong Tawah dengan model bertahap, yang berisikan beberapa topik bahasan, sehingga peserta dapat memahami sampai dengan suatu standar yang dapat dinyatakan siap mengadakan pembelajaran secara daring keseluruhan dengan memanfaatkan media online yang tersedia.

2. Diperlukan Pengabdian Serupa dengan Topik, penggunaan E-Learning berbasis Web Moodle yang dapat membuat proses belajar selama pandemi dapat lebih menarik dan interaktif.

\section{UCAPAN TERIMA KASIH}

Ucapan terima kasih disampaikan kepada Universitas Mataram dan Lembaga Penelitian dan Pengabdian Kepada Masyarakat Universitas Mataram, atas bantuan dana yang diberikan melalui program, Kontrak Pengabdian Tahun Anggaran 2021 Nomor 1886/UN18.L1/Pp/2021. Serta kepada Kepala Sekolah SD Negeri 1 Terong Tawah, beserta guru dan staff yang telah bersedia memberikan izin dan mengikuti kegiatan pelatihan yang diadakan.

\section{DAFTAR PUSTAKA}

Dwiyansaputra, R., Wijaya, I. G. P. S., Bimantoro, F., Nugraha, G. S., \& Aranta, A. (2021). Pelatihan Penggunaan Aplikasi Zoom Untuk Proses Pembelajaran Daring Pada Masa Pandemi Covid-19 Di SD Negeri 10 Cakranegara. Jurnal Begawe Teknologi Informasi (JBegaTI), 2(1), 62-69. https://doi.org/https://doi.org/10.29303/jbegati.v2i1.337

Saputra, S. Y. (2017). Permainan Tradisional VS Permainan Modern Dalam Penanaman Nilai Karakter di Sekolah Dasar. ELSE (Elementary School Education Journal) : Jurnal Pendidikan Dan Pembelajaran Sekolah Dasar, 1(1), 85-94. https://doi.org/https://doi.org/10.30651/else.v1i1.873

Switrayni, N. W., Wardhana, I. G. A. W., Irwansyah;, Aini, Q., \& Salwa. (2021). Webinar Pengenalan Google Classroom Dan Google Form Sebagai Media Dan Alat Evaluasi Pembelajaran Daring Pada Masa $\begin{array}{lllll}\text { Pandemi Covid-19. Abdi Insani, } & \text { 8(1), }\end{array}$ https://doi.org/Https://Doi.Org/10.29303/Abdiinsani.V8i1.366

Widodo, A. (2021). Emergency Online Learning: How Are Students' Perceptions? Atlantis Press. www.atlantis-press.com/proceedings/sule-ic-20/125950288 
Zaenuri, \& Prastowo, A. (2021). Peran Guru dalam Perencanaan Pembelajaran Berbasis Aplikasi Zoom Meeting di Sekolah Dasar. Edukatif: Jurnal Ilmu Pendidikan, 3(4), 1734-1744. https://doi.org/https://doi.org/https://doi.org/10.31004/edukatif.v3i4.654 